\title{
SISTEM PENDUKUNG KEPUTUSAN PEMILIHAN PABRIK OBAT MENGGUNAKAN METODE ELECTRE (METODE ELIMINATION ET CHOIX TRADUISANT LA REALITE) PADA RUMAH SAKIT PERMATA HATI BERBASIS WEB”.
}

\author{
Muhammad Reza Putra,Faradila Mustika, Eka Praja Wiyata Mandala \\ Universitas Putra Indonesia YTPK Padang \\ Email : $\underline{\text { muhammad reza@upiyptk.ac.id }}$
}

\begin{abstract}
ABSTRAK
Demikian pesatnya permintaan akan obat-obatan membuat Rumah Sakit Permata Hati memiliki kecenderungan untuk memilih lebih dari satu pabrik obat ,Hal ini disebabkan pemenuhan aspek antisipasi pada kebutuhan obat yang sering berubah dengan kondisi yang kurang menentu. Keadaan ini membawa Rumah Sakit Permata Hati kebingungan dalam memilih pabrik obat yang akan dijadikan sebagai pemasok pada rumah sakit khususnya kepada dokter yang memberikan keputusan pada permasalahan pemilihan pabrik obat, karena proses pemilihan pabrik merupakan bagian yang penting di dalam aktivitas pembelian karena berdampak pada kualitas dan ketersediaan bahan baku, efisiensi biaya pengeluaran, dan kelancaran sirkulasi keuangan rumah sakit. Untuk mengatasi hal tersebut diperlukan suatu sistem pendukung keputusan (SPK) yang dapat mengakomodasi kriteriakriteria , Proses pemilihan pabrik dilakukan dengan metode Electre (elimination et choix traduisant la realite), yaitu dengan melakukan outranking menggunakan indifference, defference dan threshold. Adapun keluaran dari sistem pendukung keputusan (SPK) ini berupa perankingan dalam pemilihan pemasok pabrik obat terbaik dan informasi yang dipilih secara objektif bagi pengambil keputusan yang dapat dijadikan acuan untuk mengambil keputusan dalam proses pemilihan pabrik obat
\end{abstract}

Kata Kunci: rumah sakit Permata hati, Metode electre, Pabrik obat.

\section{Latar Belakang}

Pabrik Obat adalah perusahaan berbadan hukum yang memiliki izin dari Menteri untuk melakukan kegiatan produksi serta penyaluran obat dan bahan obat, termasuk psikotropika. (Pasal 1 Ayat 2 UU Nomor 5 Tahun 1997 Tentang Psikotropika).Ketersedian obat di rumah sakit terkait erat dengan kulitas layanan kesehatan yang di berikan rumah sakit Peramata Hati ,Keberadaan obat yang di butuhkan, akan membantu merawat bahkan memberikan kehidupan bagi sekelompok pasien. Demikian pesatnya permintaan akan obat-obatan membuat Rumah Sakit Permata Hati memiliki kecenderungan untuk memilih lebih dari satu pabrik obat ,Hal ini disebabkan pemenuhan aspek antisipasi pada kebutuhan obat yang sering berubah dengan kondisi yang kurang menentu. Keadaan ini membawa Rumah Sakit Permata Hati kebingungan dalam memilih pabrik obat yang akan dijadikan sebagai pemasok pada rumah sakit khususnya kepada dokter yang memberikan keputusan pada permasalahan pemilihan pabrik obat, karena proses pemilihan pabrik merupakan bagian yang penting di dalam aktivitas pembelian karena berdampak pada kualitas dan ketersediaan bahan baku, efisiensi biaya pengeluaran, dan kelancaran sirkulasi keuangan rumah sakit.

Pemilihan alternatif ini dapat disebut sebagai permasalahan terstruktur dan tidak terstruktur. Disebut terstruktur karena sebagian dari permasalahan ini dapat dipecahkan oleh prosedur perhitungan terkomputerisasi. Disisi lain, masalah ini disebut tidak terstruktur karena terdapat beberapa keputusan dari manajemen dengan skala penilaian subyektif. Untuk mengatasi hal tersebut diperlukan suatu sistem pendukung keputusan (SPK) yang dapat mengakomodasi kriteria-kriteria yang diantaranya indikasi obat (suatu kondisi penyakit yang 
dapat diobati dengan obat tersebut dengan kata lain obat tersebut digunakan, diperuntukkan atau ditujukan oleh apa dan siapa), khasiat obat (manfaat yang ditimbulkan dari mengkonsumsi obat tersebut bagi pasien), efek samping obat (suatu reaksi yang tidak diharapkan dan berbahaya yang diakibatkan oleh suatu pengobatan. Efek samping obat, seperti halnya efek obat yang diharapkan, merupakan suatu kinerja dari dosis atau kadarobat pada organ sasaran), merek obat terbagi atas dua yaitu (merek dagang adalah obat yang diproduksi oleh perusahaan obat yang telah dipatenkan dan merek generik adalah obat yang merupakan tanggung jawab pemerintah dalam mengupayakan kesehatan masyarakat), harga obat (harga obat yang ditawarkan pabrik obat dan garansi obat (pemberian jaminan dari pabrik obat apabila terdapat kemasan obat yang rusak) yang termasuk kepada penilaian pemilihan pabrik.

Proses pemilihan pabrik dilakukan dengan metode Electre (elimination et choix traduisant la realite), yaitu dengan melakukan outranking menggunakan indifference, defference dan threshold. Adapun keluaran dari sistem pendukung keputusan (SPK) ini berupa perankingan dalam pemilihan pemasok pabrik obat terbaik dan informasi yang dipilih secara objektif bagi pengambil keputusan yang dapat dijadikan acuan untuk mengambil keputusan dalam proses pemilihan pabrik obat. Model pengambilan keputusan dan pemodelan sistem dituangkan dalam suatu aplikasi yang mana nantinya akan dimanfaatkan oleh rumah sakit dalam memenuhi kebutuhan yang berkesinambungan terhadap obat serta menjalin hubungan yang lebih baik dengan pabrik obat sebagai penyedia obat serta proses pengadaan obat menjadi lebih mudah dan efisien. Dengan demikian ketersediaan akan obat dapat terus terjaga.

Berdasarkan penelitian yang dilakukan oleh Citra Meryana bahwa dengan menggunakan metode Electre memperlihatkan hasil yang dapat diterima oleh para pembuat keputusan dan yang paling penting telah memberikan perankingan lengkap alternatif dalam project, karena di dalam metode Electre menggunakan indikasi dan nilai-nilai threshold, concordance dan discordance dengan memilih alternatif yang lebih disukai dari kriteria dan tidak menyebabkan suatu level penolakan ketidak puasan untuk setiap kriteria(Meryana, 2007).

\section{Analisa Dan Perancangan}

Nilai bobot preferensi untuk setiap alternatif yaitu : $W=(3,4,3,4)$ (Ketentuan).Matriks keputusan yang diambil dari tabel kecocokan ini yaitu :

$$
X=\left(\begin{array}{llll}
5 & 3 & 3 & 4 \\
3 & 4 & 4 & 5 \\
2 & 3 & 3 & 3 \\
4 & 3 & 4 & 4 \\
2 & 1 & 3 & 3
\end{array}\right)
$$

Penyelesaian

A. Membuat matriks keputusan berdasarkan pertimbangan pembuat keputusan dan menormalisasi nilai pada matriks keputusan tersebut.

$$
\begin{aligned}
& \mathrm{R}=\frac{x_{i j}}{\sqrt{\sum_{i=1}^{m} x^{2} i j}} \\
& \mathrm{R} 11=\frac{5}{\sqrt{5^{2}+3^{2}+2^{2}+4^{2}+2^{2}}}=\frac{5}{\sqrt{58}}=\frac{5}{7,615}=0.656
\end{aligned}
$$

Dan seterusnya

$\begin{array}{cccc}0,656 & 0,452 & 0,390 & 0,462 \\ 0,394 & 0,603 & 0,521 & 0,577 \\ 0,263 & 0,452 & 0,390 & 0,346 \\ 0,525 & 0,452 & 0,521 & 0,462 \\ 0,263 & 0,151 & 0,390 & 0,346\end{array}$


$\mathrm{R}=$

B. Memberikan nilai bobot pada matriks yang telah dinormalisasi dengan rumus :

$$
\mathrm{V}=\mathrm{R} . \mathrm{W}
$$

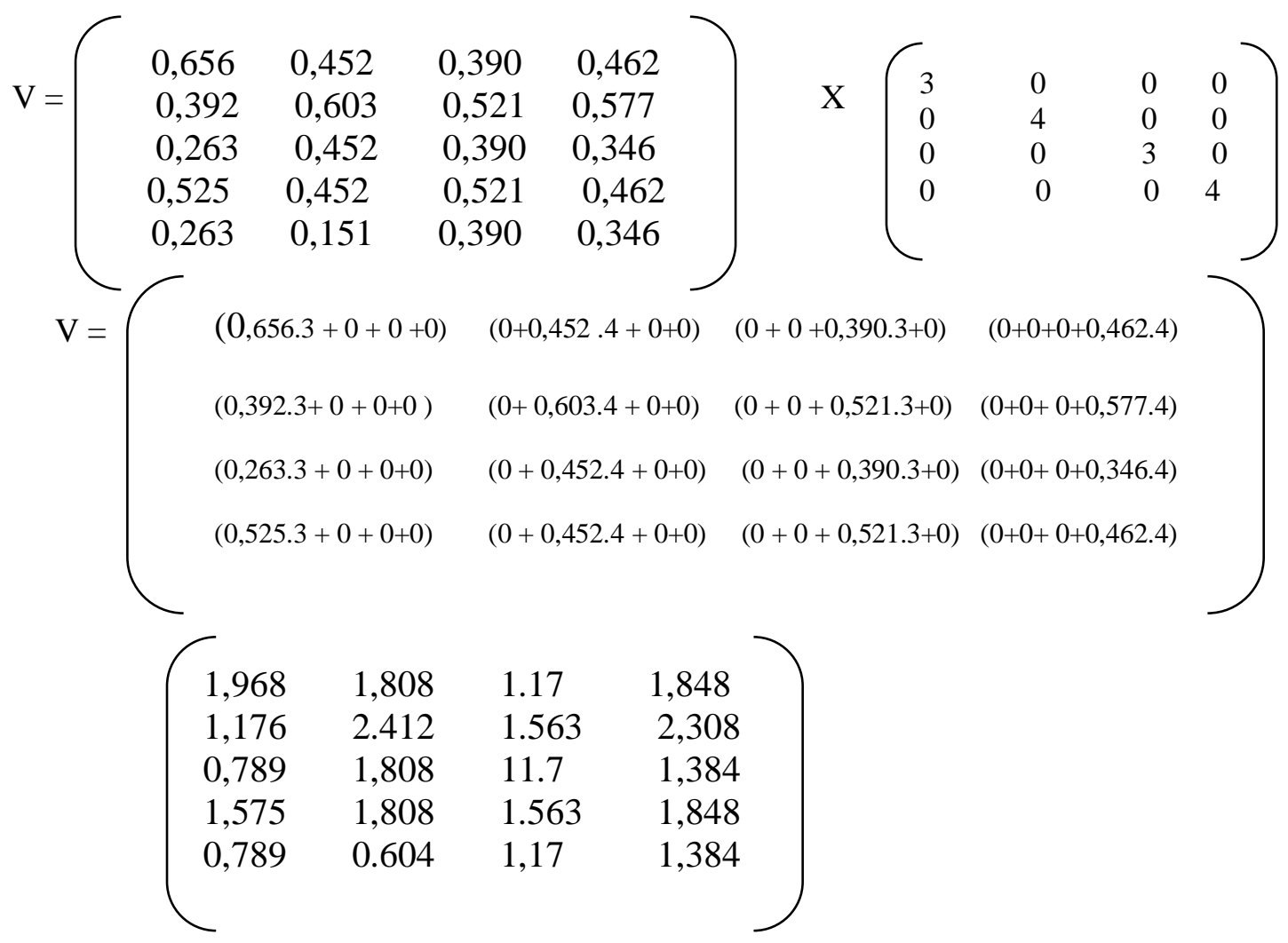

C. Menentukan himpunan corcondance dan disordance index untuk setiap pasang dari alternatif

a. Corcondance Index, $C k l=\{j, v k j \geq v l j\}$, untuk $\mathrm{j}=1,2,3, \ldots, \mathrm{n}$
$\mathrm{C} 12=\{1\}$
$\mathrm{C} 13=\{1,2,4\}$
$\mathrm{C} 14=\{1,2,4\}$
$\mathrm{C} 31=\{2,3\}$
$\mathrm{C} 32=\{3\}$
$\mathrm{C} 34=\{2,3\}$
$\mathrm{C} 15=\{1,2,3,4\}$
$\mathrm{C} 35=\{1,2,3,4\}$
$\mathrm{C} 21=\{2,3,4\}$
$\mathrm{C} 23=\{1,2,4\}$
$\mathrm{C} 41=\{2,3,4\}$
$\mathrm{C} 42=\{1,3\}$
$\mathrm{C} 24=\{2,3,4\}$
$\mathrm{C} 43=\{1,2,4\}$
$\mathrm{C} 25=\{1,2,3,4\}$
$\mathrm{C} 45=\{1,2,3,4\}$
$\mathrm{C} 51=\{3\}$
$\mathrm{C} 52=\{0\}$
$\mathrm{C} 53=\{1,4\}$
C54=\{0\}

b. Disordance Index, $D k l=\{j, v k j<v l j\}$, untuk $\mathrm{j}=1,2,3, \ldots, \mathrm{n}$
D12 $=\{2,3,4\}$
D31 $=\{1,4\}$
D51 $=\{1,2,4\}$
$\mathrm{D} 13=\{3\}$
D14 $=\{3\}$
D32 $=\{1,2,4\}$
D34 $=\{1,4\}$
D52 $=\{1,2,3,4\}$
D15 $=\{0\}$
D35 $=\{0\}$
D53 $=\{2,3\}$
D54 $=\{1,2,3,4\}$
D21 $=\{1\}$
D41 $=\{1\}$
D23 $=\{3\}$
D42 $=\{2,4\}$ 

$\mathrm{D} 24=\{1\}$
$\mathrm{D} 25=\{0\}$
$\mathrm{D} 43=\{3\}$
$\mathrm{D} 45=\{0\}$

D. Menghitung matriks corcondance dan discordance dengan cara menjumlahkan bobot yang termasuk pada himpunan

a. Corcondance

$$
\mathrm{Ckl}=\sum_{j \in C k l} w j
$$

$$
\mathrm{W}=\{3,4,3,4\}
$$

$\mathrm{C} 12=\mathrm{w} 1=3$

$\mathrm{C} 13=\mathrm{w} 1+\mathrm{w} 2+\mathrm{w} 4=3+4+4=11$

$\mathrm{C} 34=\mathrm{w} 2+\mathrm{w} 3=4+3=7$

$\mathrm{C} 35=\mathrm{w} 1+\mathrm{w} 2+\mathrm{w} 3+\mathrm{w} 4=3+4+3+4=14$

$\mathrm{C} 41=\mathrm{w} 2+\mathrm{w} 3+\mathrm{w} 4=4+3+4=11$

$\mathrm{C} 42=\mathrm{w} 1+\mathrm{w} 2=3+3=6$

$\mathrm{C} 43=\mathrm{w} 1+\mathrm{w} 2+\mathrm{w} 4=3+4+4=11$

$\mathrm{C} 45=\mathrm{w} 1+\mathrm{w} 2+\mathrm{w} 3+\mathrm{w} 4=3+4+3+4=14$

$\mathrm{C} 51=\mathrm{w} 3=3$

C52 $=0$

$\mathrm{C} 53=\mathrm{w} 1+\mathrm{w} 2+\mathrm{w} 3+\mathrm{w} 4=3+4+3+4=14$

$\mathrm{C} 54=0$

$\mathrm{C} 32=\mathrm{w} 3=3$

Hasil : $\quad\left(\begin{array}{ccccc}- & 3 & 11 & 11 & 14 \\ 11 & - & 11 & 11 & 14 \\ 7 & 3 & - & 7 & 14 \\ 11 & 6 & 11 & - & 14 \\ 3 & 0 & 7 & 0 & -\end{array}\right)$

$$
\begin{aligned}
& \text { b. Discordance } \\
& \mathrm{Dkl}=\frac{\max \{|v k j-v l j|\} j \in D k l}{\max \{|v k j-v l j|\} \forall j} \\
& \mathrm{~V}=\left(\begin{array}{cccc}
1,968 & 1,808 & 1.17 & 1,848 \\
1,176 & 2.412 & 1.563 & 2,308 \\
0,789 & 1,808 & 11.7 & 1,384 \\
1,575 & 1,808 & 1.563 & 1,848 \\
0,789 & 0.604 & 1,17 & 1,384
\end{array}\right) \\
& \mathrm{D} 12=\frac{\max \{[1,808-2,412] ;[1,17-1,563] ;[1,848-2,308]\}}{\max \{[1,968-1,176] ;[1,808-2,412] ;[1,17-1,563] ;[1,88-2,308]\}} \\
&=\frac{\max \{[0,604] ;[0,393][0,46]\}}{\max \{[1,176] ;[0,604] ;[0,393] ;[0,46]\}}=\frac{0,604}{1,176}=0,762 \\
& \mathrm{D} 13=\frac{\max \{[1,17-11,7]\}}{\max \{[1,968-0,789] ;[1,808-1,808] ;[1,17-11,7] ;[1,848-2,308]\}} \\
&=\frac{\max \{[10,53]\}}{\max \{[1,179] ;[0] ;[10,53] ;[0,460]\}}=\frac{10,53}{10,53}=1
\end{aligned}
$$


E. Menghitung matrik domain concordance dan discordance

a. Menghitung matriks domain corcondance, matriks $f$ sebagai matriks domain corcondance dapat dibangun dengan bantuan nilai threshold yaitu dengan membandingkan setiap elemen matriks corcondance dengan nilai threshold. $\quad \underline{\mathrm{C}}=\frac{\sum_{k=1}^{m} \sum_{l=1}^{m} c k l}{m(m-1)}$

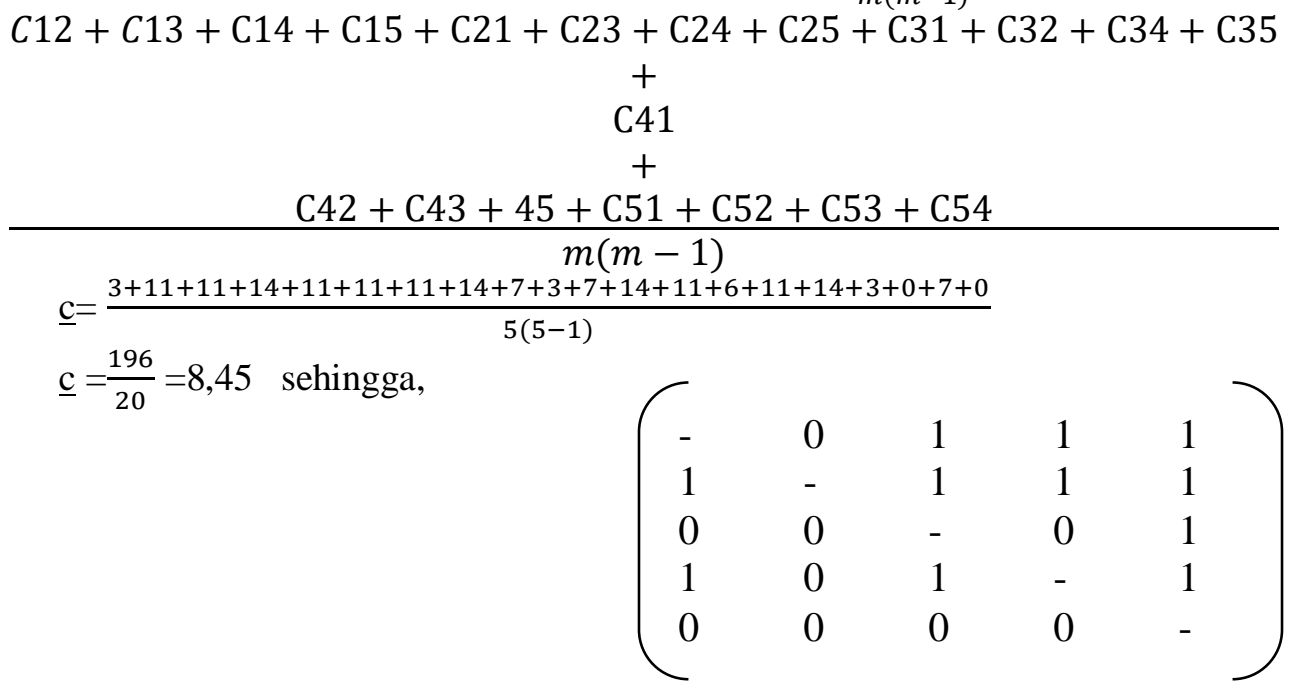

b. menghitung matriks domain discordance, matriks g sebagai matriks domain discordance dapat dibangun dengan bantuan nilai threshold ( $\underline{\mathrm{d}}$ ) yaitu $\underline{\mathrm{d}}=\frac{\sum_{k=1}^{m} \sum_{l=1}^{m} c k l}{m(m-1)}$

$$
\begin{aligned}
& \underline{\mathrm{d}}=\frac{\frac{d 12+d 13+\mathrm{d} 14+\mathrm{d} 15+\mathrm{d} 21+\mathrm{d} 23+\mathrm{d} 24+\mathrm{d} 25+\mathrm{d} 31+\mathrm{d} 32+\mathrm{d} 34+\mathrm{d} 35+\mathrm{d} 41+\mathrm{d} 42+\mathrm{d} 43+\mathrm{d} 45+\mathrm{d} 51+}{\mathrm{d} 52+\mathrm{d} 53+\mathrm{d} 54}}{m(m-1)} \\
& \underline{\mathrm{d}} \frac{0,762+1+1+0+1+1+0,66+0,602+0+0,602+0,09+0.077+0+1+1+1+0+1+1+1+1}{5(5-1)} \\
& \underline{\mathrm{d}}=\frac{12,045}{20}=0,6023 \text { sehingga, }\left(\begin{array}{ccccc}
- & 0 & 1 & 1 & 0 \\
1 & - & 1 & 1 & 0 \\
0 & 0 & - & 0 & 0 \\
1 & 1 & 1 & - & 0 \\
1 & 1 & 1 & 1 & -
\end{array}\right)
\end{aligned}
$$

F. Menentukan agregate dominance matriks. Matriks e sebagai agregate dominance matriks adalah matriks yang setiap elemen merupakan perkalian matriks gf dan matriks $\mathrm{g}$ yang bersesuaian. Secara matematis dinyatakan dengan : ekl $=\mathrm{fkl} \mathrm{x} \mathrm{gkl}$
$\mathrm{E} 12=0 \times 0=0$
$\mathrm{E} 31=0 \times 0=0$
$\mathrm{E} 13=1 \times 1=1$
$\mathrm{E} 32=0 \times 0=0$
$\mathrm{E} 14=1 \times 1=1$
$\mathrm{E} 34=0 \times 0=0$
$\mathrm{E} 15=1 \times 0=0$
$\mathrm{E} 35=1 \times 0=1$
$\mathrm{E} 21=1 \times 1=1$
$\mathrm{E} 41=1 \times 1=1$
$\mathrm{E} 23=1 \times 1=1$
$\mathrm{E} 42=0 \times 1=0$
$\mathrm{E} 24=1 \times 1=1$
$\mathrm{E} 43=1 \times 1=1$
$\mathrm{E} 25=1 \times 0=0$
$\mathrm{E} 45=1 \times 0=0$

$\mathrm{E} 51=0 \times 1=0$

$\mathrm{E} 52=0 \times 1=0$

$\mathrm{E} 53=0 \times 1=1$

$\mathrm{E} 54=0 \times 01=0$

Sehingga matriks yang dihasilkan:

$23\left(\begin{array}{ccccc} & 0 & 1 & 1 & 0 \\ 1 & - & 1 & 1 & 0 \\ 0 & 0 & - & 0 & 0 \\ 1 & 0 & 1 & - & 0 \\ 0 & 0 & 0 & 0 & -\end{array}\right)$




$$
\mathrm{e}=
$$

G. Eliminasi

Eliminasi alternatif yang less favourable. Matriks e merupakan urutan pilihan dari setiap alternatif yaitu apabila ekl=1 maka, alternatif ekl merupakan alternatif yang lebih baik dari pada a2, sehingga baris pada matriks e yang memiliki jumlah ekl=1 paling sedikit dapat dieliminasi. Dengan demikian alternatif terbaik adalah alternatif yang mendominasi alternatif lainnya Dan kesimpulan dari langkahlangkah diatas adalah Alternatif yang berhak menjadi pemasok pabrik obat Pt. Dexamedica.

diagram, statechart diagram, dan deployment diagram.

\section{Use Case Diagram}

Use Case Diagram menggambarkan apa saja aktifitas yang dilakukan oleh suatu sistem dan hubungan aktor-aktor yang terlibat, untuk lebih jelasnya perancangan use case diagram pada aplikasi sistem pendukung keputusan ini dapat dilihat pada Gambar 4.1:

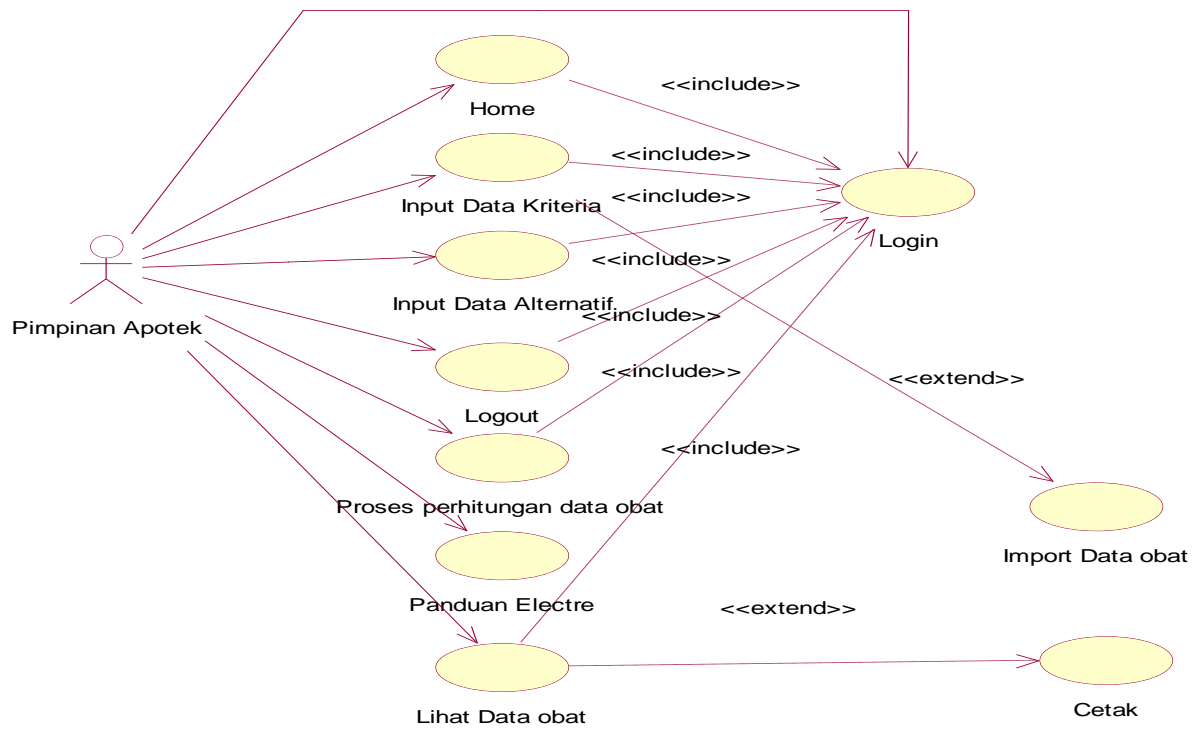

\section{Gambar 1 Use Case Diagram SPK}

\section{Interface Sistem Pendukung Keputusan}

Interface Halaman Index

Berikut adalah tampilan dari Halaman Index:

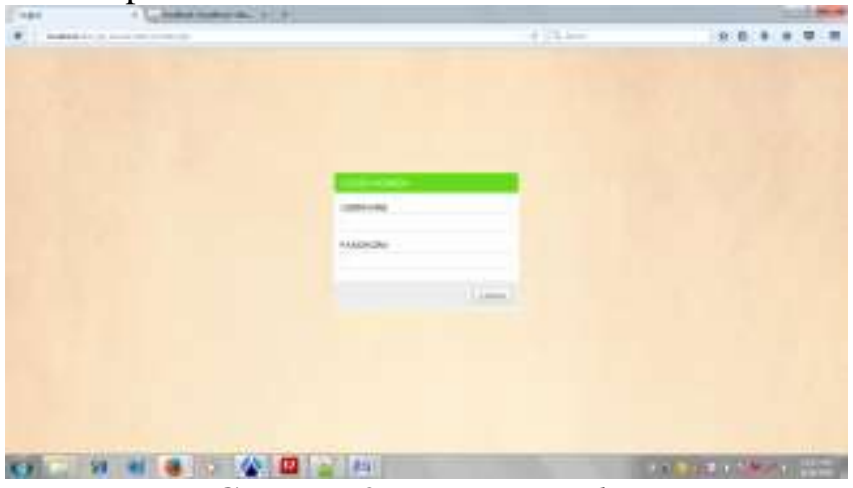

Gambar 2 Halaman Index 
Gambar diatas merupakan gambar Interface dari halaman Index, Dimana halaman tersebut tampil pada saat pertama pemimpin apotik mengakses sistem pendukung keputusan ini.

\section{Interface Halaman Login Pemimpin Apotik}

Berikut adalah tampilan dari halaman login Pemipin Apotik:

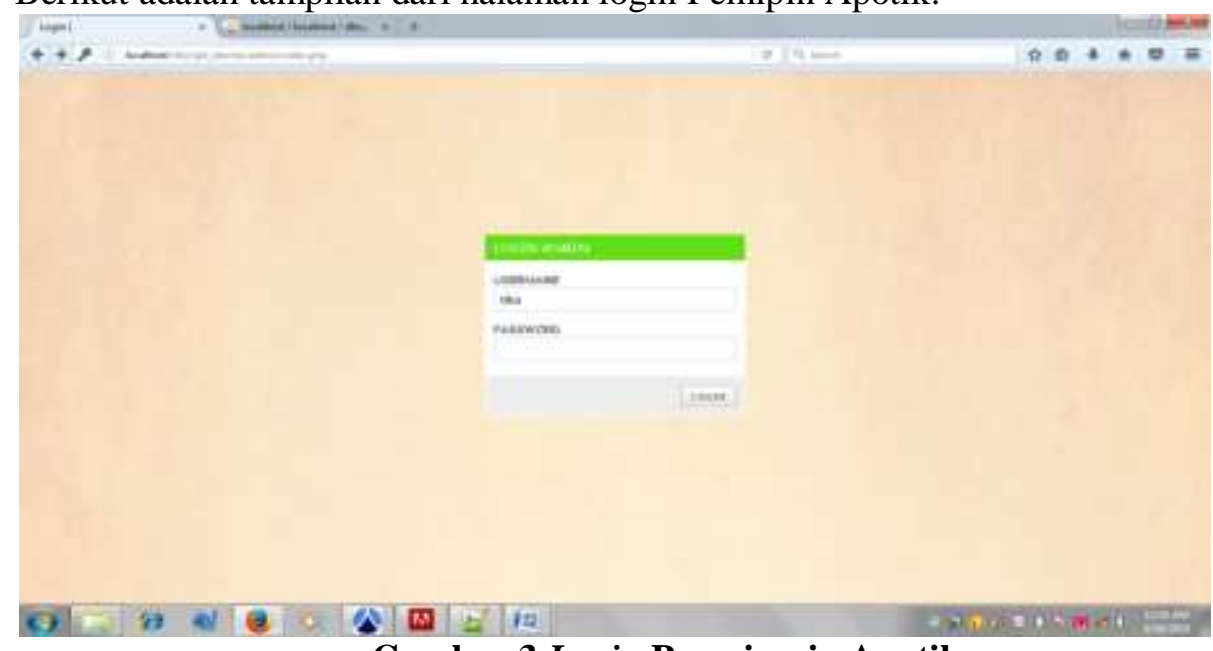

\section{Gambar 3 Login Pempimpin Apotik}

Gambar diatas merupkan interface login pemimpin, dimana Pemimpin harus memasukan username dan juga password terlebih dahulu kemudian klik login, jika berhasil maka sistem akan mengarahkan Pemimpin ke halaman home.

\section{Interface Menu Pemimpin Apotik}

Berikut adalah interface dari Menu Pemmpin Apotik:
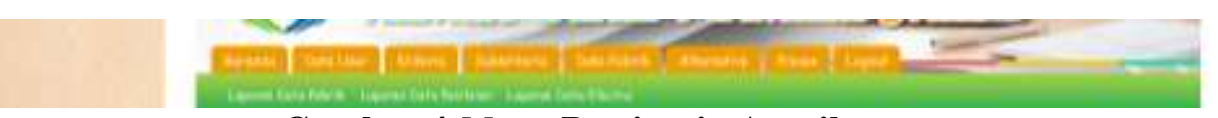

\section{Gambar 4 Menu Pemimpin Apotik}

Gambar diatas merupkan interface menu ketua, dimana terdapat menu home, kelola kriteia, perengkingan, keputusan dan juga logout.

\section{Interface Form Input Data Penilaian Dari Calon Pemasok}

Berikut adalah interface form input data calon pemasok pabrik obat:

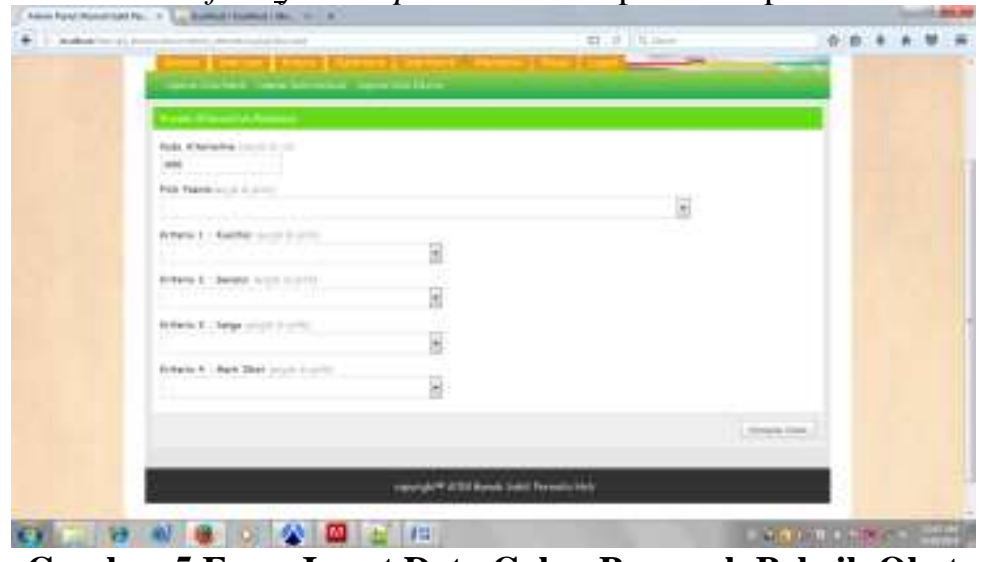

Gambar 5 Form Input Data Calon Pemasok Pabrik Obat 

struktural:

\section{Interface Perengkingan Dari Masing-Masing Bagian}

Berikut adalah Halaman Perengkingan Calon dari masing-masing bagian pada

\section{Interface Hasil Keputusan}

Berikut adalah hasil kepututsan dari sistem pendukung keputusan ini:

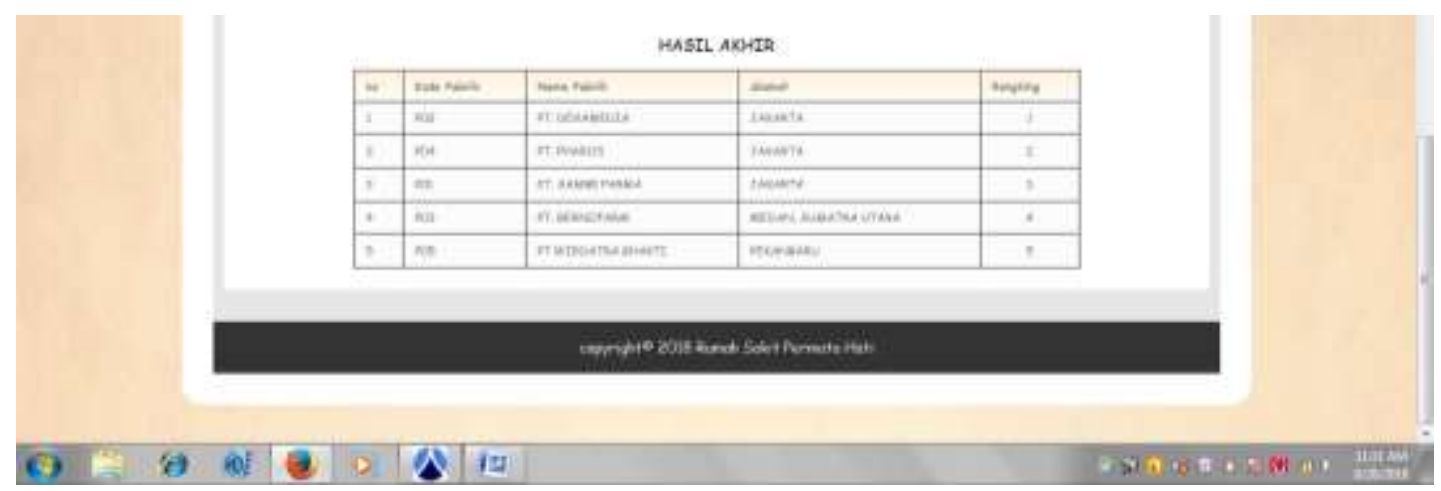

\section{Gambar 6 Hasil Keputusan}

Gambar diatas merupkan interface dari hasil keputusan yang diambil yaitu alternative yang mendominasi alternative lainya dan kesimpulan dari sitem tersebut adalah yang berhak pemasok pabrik obat pada rumah sakit permata hati yaitu PT Dexa Medica.

\section{Kesimpulan}

Dari penulisan penelitian ini mulai dari tahapan analisa permasalahan yang ada hingga pengujian sistem yang baru dirancang maka dapat diambil beberapa kesimpulan, yaitu :Dengan menggunakan Sistem Pendukung Keputusan ini dapat menghasilkan keputusan yang terbaik, karena mempertimbangkan kriteria-kriteria yang sesuai dengan masing-masing kriteria yang di inginkan rumah sakit dan mencocokannya dengan nilai yang ada pada masing-masing calon pemasok obat. Dengan cara menginputkan data pemasok dapat memberikan informasi dapat mempermudah Pemimpin dalam menghasilkan keputusan yang cepat dan tepat karna menggunakan metode Logika Electre dimana metode ini mengolah data secara adil terhadap semua krteria yang ada.

\section{Referensi}

Dermanto, Eko, dkk. 2014. Penerapan Metode Ahp (Analythic Hierarchy Process) Untuk Menentukan Kualitas Gula Tumbu. Jurnal SIMETRIS. Vol 5 No 1. ISSN: 22524983.

Hayati, gusti, TA. 2010.Sitem pendukung keputusan dalam supplier obat menggunakan metode Electre pada rumah sakit ibu dan anak mutia sari duri. Jurnal teknik informatika Universitas Islam Negeri Sultan Syarif Kasim Riau .

Kurniasih, Desi Leha. 2013. Sistem Pendukung Keputusan Pemilihan Laptop Dengan Metode TOPSIS. Jurnal Pelita Informatika Budi Darma. Volume III No 2. ISSN: 2301-9425.

Kusumadewi, Sri, dkk. 2010. Aplikasi Logika Fuzzy untuk Pendukung Keputusan, Edisi 2. Yogyakarta: Graha Ilmu. 
Lenti, Febri Nova. 2014. Rekayasa Database Terdistribusi Pada Layanan Pemesanan Tiket Pesawat Terbang. Jurnal Teknologi Technoscientia. Vol. 6 No. 2. ISSN: 1979-8415

Mandala, Eka Praja Wiyata. 2015.Web Programing project 1"e.p.w.m forum. padang: Teknik Informatika.

Marlinda, Linda. 2016 Sistem Pendukung Keputusan Pemilihan Tempat Wisata Yogyakarta Menggunakan Metode ELimanation Et Choix Traduisant La Realita( ELECTRE). Jurnal Teknik Komputer AMIK Bina Sarana Informatika. ISSN: 24078416

Mandala, Eka Praja Wiyata. 2015.Web Programing project 1"e.p.w.m forum. padang: Teknik Informatika

Mulyanto, Aunur R. 2009. Rekayasa Perangkat Lunak, Jilid 1. Jakarta: Direktorat Pembinaan Sekolah Menengah Kejuruan.

Nugroho, Adi. 2005. Rational Rose untuk Pemodelan Berorientasi Objek. Bandung: Informatika.

Nugroho, Dedi Prasetyo, dkk. 2010. Pembuatan E-Commerce Toko Sepatu Actifa. Indonesian Journal on Networking and Security. ISSN: 2302-5700.

S, Rosa dan M. Shalahuddin. 2014. Rekayasa Perangkat Lunak Terstruktur dan Berorientasi Objek, Jilid 2. Bandung: Informatika.

(Siregar, 2004:289).

Saragih, Arif Semdela. 2014. Sistem Pendukung Keputusan Pengangkatan Kepala Sekolah Rayon Yp. GKPS Dengan Metode ELECTRE (Elimination Choice Translation Reality). Jurnal Informasi dan Teknologi IImiah (INTI). Volume : IV, No 3. ISSN: 2339-210X.

Sidik, Betha. 2012. Pemrograman Web PHP Edisi Revisi. Bandung: Informatika.

Taufiq, Ghofar. 2014. Logika Fuzzy Tahani Untuk Pendukung Keputusan erekrutan Karyawan Tetap. Jurnal Prosiding Seminar Nasional Aplikasi Sains \& Teknologi (SNAST) 2014. ISSN: 1979-911X.

Warman, Firman, dkk. 2013. Rekayasa Web Untuk Pemesanan Handphone Berbasis Jquery Pada Permata Cell. Jurnal Momentum.Vol.15 No.2. ISSN: 1693-752X. 